\title{
Homeobox Protein Hox-A13
}

National Cancer Institute

\section{Source}

National Cancer Institute. Homeobox Protein Hox-A13. NCI Thesaurus. Code C97573.

Homeobox protein Hox-A13 (388 aa, $40 \mathrm{kDa}$ ) is encoded by the human HOXA13 gene.

This protein plays a role in skeletal development. 